I Would be Rather Pleased if the World Were to be Rid of Monks.

Resistance to Cluniac Integration

in Late Eleventh- and Early Twelfth-Century France

\author{
Steven Vanderputten (Ghent University) \\ Department of History, Ghent University \\ Sint-Pietersnieuwstraat 35, 9000 Gent (Belgium) \\ Steven.Vanderputten@ugent.be
}




\section{Would be Rather Pleased if the World Were to be Rid of Monks. Resistance to Cluniac Integration in Late Eleventh- and Early Twelfth-Century France}

Abstract: This paper takes a bottom-up look at Cluniac integration in the decades on either side of the year 1100 in order to explore the diverse institutional, contextual, and personal dynamics at play. Taking as its case study the French diocese of Saintes, it charts the transformation of the ecclesia Cluniacensis, the impact on relations with monastic houses in the region, and the response by diverse stakeholders. It reveals that local groups of monks and their patrons actively participated in the then-ongoing integration of monastic administration, facilitating the exchange of personnel and know-how. But they also expected these processes to be subject to negotiation and compromise: and when the Cluniacs challenged these expectations the destabilizing effect on Saintes society was profound. As such, this study helps to adjust a former narrative that contrasted the Cluniacs' reform of monastic administration in this period with the resistant attitude of individual communities and their local patrons.

Keywords: monasticism, monastic reform, monastic integration, Cluniac federation, diocese of Saintes, confraternities, abbatial appointments, mortuary rolls

Sometime in late 1113 or early 1114 a weary messenger arrived at Saint-Eutrope, a Cluniac priory in the episcopal town of Saintes near the Atlantic coast of France. Over the course of several months, he had visited no fewer than 142 communities of religious men or women in Normandy, England and Brittany, travelling as far south as Saintes' own Charente region. And on each of these occasions he had offered for inspection the mortuary roll of Abbess Mathilde of Sainte-Trinité in Caen (d. 6 July 1113), which opened 
with an account (littera or encyclica) of the abbess' virtues and pious death and a large miniature that presumably pictured her on her deathbed. ${ }^{1}$ Custom dictated that his hosts would first read the littera and any added materials from previous stages of his journey. Then they would add a titulus that typically consisted of a brief note of condolence, a few names of individuals they wished to remember, and a poem in honour of the deceased. ${ }^{2}$ But at Saint-Eutrope, the individual who was tasked with composing the monks' titulus decided not to waste his poetic energies on remembering Mathilde. Instead, he lamented the pitiful situation in which all monks now found themselves:

${ }^{1}$ The reconstructed contents of the roll, which survives only in partial copies from the seventeenth and eighteenth centuries, are edited in Recueil des rouleaux des morts, VIIIe siècle-vers 1536, ed. Jean Dufour, 5 vols. (Paris: Académie des inscriptions et belleslettres, 2005-13), 1: 392-502. For a discussion, see Monique Goullet, 'Poésie et mémoire des morts. Le rouleau funéraire de Mathilde, abbesse de la Sainte-Trinité de Caen (+ 1113)', in Ad libros! Mélanges d'études médiévales offertes à Denise Angers et JosephClaude Poulin, ed. Jean-François Cottier (Montréal: Presses de l'Université de Montréal, 2010), 163-98; and Ead., 'De Normandie en Angleterre: Enquête sur la poétique de trois rouleaux mortuaires', in Autour de Serlo de Bayeux: La poésie normande aux XIe-XIIe siècles. Special issue of Tabularia (2016), https://journals.openedition.org/tabularia/2782 (accessed 24 June 2019). On Mathilde's identity and the fallacy of earlier assumptions about her kinship to William the Conqueror and his wife Mathilde, Goullet, 'Poésie', 170-2. ${ }^{2}$ Goullet, 'Poésie'. On the genre of mortuary rolls in the later eleventh and early twelfth centuries, see also the richly annotated papers in Bruno the Carthusian and his Mortuary Roll: Studies, Text, and Translations, ed. Hartmut Beyer, Gabriela Signori, and Sita Steckel (Turnhout: Brepols, 2014). 
The cohort of monks enjoy the fate of the blessed/Now they are thrown down, then they are looked down on as vile/They pray for all and weep over the crimes of others/The vile, those covered in rags, all of them are precious to the Lord/But those of you who laugh, see nothing with reason/Your moaning minds curse from insanity/Crying, moaning, immoderate pain/Will befall you, you will be the crying ones and you will then be those mourning over these things/The monks are (now) in mourning and utter pain/Trusting no-one but themselves, in fear of being put to trial/They await the dire anger of the Strict Judge/The coming of the Judge, for whom all that is hidden up will be visible. ${ }^{3}$

We have no indication that the Sainte-Trinite rolliger (literally 'roll-carrier') felt disturbed when he saw these remarkable lines of verse. Although the practice drew considerable criticism at the time, ${ }^{4}$ people in his occupation were used to local annotators

${ }^{3}$ Recueil, ed. Dufour, 461: 'Sorte beatorum fruitur coetus monachorum/Nunc affliguntur, nunc viles despiciuntur/Pro cunctis orant alienaque crimina plorant/Viles, pannosi, Domino fiunt preciosi/At qui ridetis, nichil ex ratione videtis/Dampnant gementes vestras insania mentes/Vobis ploratus, gemitus, dolor immoderatus/Accedet; flentes eritis tunc ista luentes/Sunt in moerore monachi nimioque dolore/Nil sibi fidentes, de judicio metuentes/Expectant diram districti Judicis iram/Judicis adventum, quo quaeque retecta patebunt'.

${ }^{4}$ The churchman and poet Baudri of Bourgeuil (d. 1130) urged his contemporaries to refrain from inscribing frivolous content on mortuary rolls; Baldricus Burgulianus. Carmina, ed. Jean-Yves Tilliette, 2 vols. (Paris: Belles Lettres, 1998), 1: nr. 14, p. 39 and 
of mortuary rolls adding unrelated content such as commentary on current events, satire, secular verses, and even mere word play. ${ }^{5}$ And contrary to some of the deeply misogynist poetry in earlier tituli on Mathilde's roll, the Saint-Eutrope poem was unlikely to cause offence with his female patrons back in Normandy. ${ }^{6}$ But there were other readers who did not take the text for granted. When the roll travelled on to its next stop at Saint-Vivien, a small house of canons in the same town of Saintes, the community members felt targeted by the poem's provocative content and responded with violent anger. On being asked to submit a titulus for his community, one of the members drafted a scorching literary attack of sixty-seven verses against Cluniac monks and their evil ways:

nr. 17, p. 40. His contemporary Marbod of Rennes (d. circa 1123) voiced similar concerns (Jacques Paul Migne, Patrologia Latina, 171: c. 1675), as did others whose remarks are edited in Recueil, ed. Dufour, 240 (littera of the roll of Bernard of Marmoutier, d. 1100) and 377 (titulus by the monks of Cluny on the roll of Hugo of Saint-Amand, d. 1107).

${ }^{5}$ On funerary poetry in this period, Jean-Claude Kahn, Les moines messagers. La religion, le pouvoir et la sicence saisis par les rouleaux des morts, XIe-XIIe siècles (Mesnil-surLestré: Jean-Claude Lattès, 1987), 155-94; Goullet, 'Poésie'; Ead., 'De Normandie en Angleterre'; and the contributions in Bruno the Carthusian, ed. Beyer, Signori, and Steckel. ${ }^{6}$ One of these, by a group of scolares from Bath cathedral, satirizes nuns' alleged penchant for love-making (Recueil, ed. Dufour, nr. 28, p. 409). It reminds us (among other satirical texts of the period) of a mid-twelfth-century polemical poem known as the Love council of Remiremont; Das Konzil der fröhlichen Fräulein von Remiremont. Concilium in monte Romarici, ed. Alexander Schulz (Butjadungen: Butjadingen-Burhave M.M.O., Verl. zur Förderung des Mittel- und Neulateinischen, 2013). 
If this roll would be about the death of a monk/The death of that monk would give me much pleasure/I would be rather pleased if the world were to be rid of monks/The infernal struggle may fill with them/Others will enter the eternal kingdom under the stars. ${ }^{7}$

Monks, he continued, used to be saints, always dedicated to the service of God and glorified by their merits across the world, looking to settle in mountains and forests, and sober in their diet, clothing, and all other things. But since then, they had changed their mode of life, gathering immense riches, becoming traders of money and administrators of churches, leading the clergy, breaking their vow of stability, frequenting castles, and taking illicit liberties with their appearance. The consequence of this 'Cluniac insanity' - for it was the Cluniacs who were to blame for all of this - were scandals too numerous to describe. In one of these, the local clergy had been outraged by the Cluniacs' attempt to steal the episcopal throne of Saintes following the death of Bishop Peter, an attempt that included disparaging the clergy's candidate. The anonymous writer concluded:

To me (the Cluniacs) ought to be enemies/They desire to be seen by the people as saintly and just/But they are unwilling to promise these things in their heart. ${ }^{8}$

\footnotetext{
${ }^{7}$ Recueil, ed. Dufour, 461-3, at 461: 'Si praesens rotulus monachi de morte fuisset/Mors illius mihi monachi multum placuisset/A monachis vellem mundum nimis (vacuari)/Posset ut infernus contentus eis saciari/Intrabunt alii regnum super astra perhenne'.

${ }^{8}$ Ibid., 463: 'Ergo, musa, tace, quamvis mihi sint inimici/A populo cupiunt sancti justique videri/Quae sunt interius nolentes illa fateri'.
} 
The Saint-Eutrope and Saint-Vivien poems were written in very different narrative registers. The former conveys the image of a religious community that is facing catastrophic physical and verbal aggression: it borrows language and arguments that monks at the time routinely used to threaten or curse their local enemies, for instance in the context of property disputes. ${ }^{9}$ In contrast, the latter is an attempt to craft an original piece of polemical writing about the decline of monastic morals and its destabilizing effect on ecclesiastical and social order. It blames this state of affairs on a Cluniac movement that falsely claims moral superiority, and it references then-current criticisms of the Cluniacs' overly formal observance and luxurious lifestyle, their institutional wealth, and their excessive involvement in lay and especially clerical affairs. ${ }^{10}$ But despite the contrast

${ }^{9}$ Lester K. Little, 'Anger in Monastic Curses', in Anger's Past: The Social Uses of an Emotion in the Middle Ages, ed. Barbara H. Rosenwein (Ithaca NY: Cornell University Press, 1998), 9-35 and Steven Vanderputten, 'Monks, Knights, and the Enactment of Competing Social Realities in Eleventh- and Early-Twelfth-Century Flanders', Speculum 84 (2009): 582-612.

${ }^{10}$ For a recent view on these criticisms and their perception in scholarship, see respectively Steven Vanderputten, 'The Dignity of Our Bodies and the Salvation of Our Souls. Reform and the Construction of Scandal in the Late Tenth Century', in Using and Not Using the Past after the Carolingian Empire, c. 900-c. 1050, ed. Stefan Esders, Sarah Greer, and Alice Hicklin (London: Taylor \& Francis, forthcoming) and Jean-Hervé Foulon, Eglise et réforme au Moyen Age. Papauté, milieux réformateurs et ecclésiologie dans les Pays de la Loire au tournant des XIe-XIIe siècles (Brussels: De Boeck, 2008), 189-230. One of several antimonastic treatises by canons from roughly the same time period is the De differentia vitae canonicorum et monachorum, edited in Jean Leclercq, 'Un temoignage sur l'influence de Gregoire VII dans la réforme canoniale', Studi Gregoriani 6 (1959/1961): 173-227. 
between the two poets' discursive approaches, it is still easy to tell that both refer to one and the same local context of disrupted relations between Cluniac monks and local agents in the Saintes area.

Unfortunately, that context has so far eluded detailed scrutiny. The handful of studies that have looked at the Saint-Vivien poem suggest that we need to understand it in relation to the troubled succession of Bishop Pierre de Soubise of Saintes (d. before 19 November 1111), more specifically in a failed attempt by Cluniac abbot Henry of SaintJean d'Angély to himself claim the episcopal throne and oust the clergy's elected candidate. ${ }^{11}$ Supposedly, Henry's actions resulted in a major backlash against local groups of Cluniacs, including the one at Saint-Eutrope. But as I hope to show in this paper, careful investigation of primary sources from the later eleventh and early twelfth centuries reveals that if we want to grasp the legal, institutional, and even emotional subtext to the two poems, we must look beyond this single incident. As it turns out, the episcopal succession crisis of 1111 must be understood as part of a much broader context of conflicts arising from the ongoing transformation of the Cluniac federation and its impact on Saintes society.

At the heart of my argument stands the observation that relations between the Cluniacs and local agents had been complex for several decades. Although members of the

\footnotetext{
${ }^{11}$ For instance in Cecily Clark, "This Ecclesiastical Adventurer': Henry of Saint-Jean d'Angély', The English Historical review 84 (1969): 548-60, at 558; J. Duguet, 'Une ville politiquement déchue (XIe siècle-XIIIe siècle)', in Histoire de Saintes, ed. Alain Michaud (Toulouse: Editions Privat, 1989), 67; and Robert Favreau, 'L'apport des rouleaux des morts à l'histoire de la région', Revue historique du Centre-Ouest 6 (2007): 165-170, at 168.
} 
aristocratic and clerical elites had been receptive to Cluny's involvement in the region's religious landscape, beginning in the 1070 s concerns arose over the status of a number of local monasteries that had become implicated in the movement. More specifically, we see that the appointment of Cluniac monks as abbots in these places led to concerns regarding the future relationship of these individuals to the abbot of Cluny, and about how this would affect the course and nature of their administration. Initially disputes arising from these concerns were resolved via negotiated compromise. However, beginning in the final years of the eleventh century the Cluniacs became more aggressive in seeking to fully integrate religious houses in their federation and in relying on local representatives to realize that agenda. Based on their own experience of subordinating smaller institutions and on their understanding of the evolving nature of Cluniac governance, several major institutions and their secular associates fiercely resisted this trend. The resulting tensions caused deep fracture lines in Saintes society and eventually led to a sobering series of confrontations in the years 1109-1112. The emotionally charged aftermath of these confrontations is documented, along with a number of other testimonies, in the two poems on Mathilde's roll.

By taking a bottom-up look at monastic integration in the late eleventh and early twelfth centuries, this case study allows us to see with greater clarity than before the diverse legal, institutional, contextual and even personal dynamics that drove this process. In addition, it helps us adjust a former narrative that contrasted the Cluniacs' pioneering of a new approach to institutional collaboration with the particularistic attitude of individual communities and their local patrons. As my study of three instances of conflict over the Cluniacs' involvement in the administration of monastic houses in the broader Saintes area will reveal, local groups of monks and their secular associates at the time were anything but resistant to institutional collaboration. We find that they actively worked to facilitate 
exchange of personnel and know-how and acknowledged that integration of monastic institutions into federational structures would ultimately benefit the monastic cohort. But at the same time, we also find that they expected these processes to be subject to negotiation and compromise. When the Cluniacs and their supporters began to challenge that expectation and intrigued in order to avoid the need for negotiations and compromises, the destabilizing effect on local societies was profound.

Cluniac Expansion in the Saintes Area

Cluniac monasticism's insertion in the diocese of Saintes and in neighbouring territories must be understood in light of the complex relationship that existed between the local abbeys and the counts of Poitou, also dukes of Aquitaine. ${ }^{12}$ At the origins of this relationship stands the abbey of Maillezais in the diocese of the same name. Founded circa 968-970, it soon emerged as a representative institution of comital power and ended up in

${ }^{12}$ Louis Bruhat, Le monachisme en Saintonge et en Aunis (XIe et XIIe siècle). Etude administrative et économique (La Rochelle: A. Foucher, 1907); René Croiset, 'Les étabilissements clunisiens en Saintonge', Annales du Midi 75 (1963): 575-81; Armin Kohnle, Abt Hugo von Cluny 1049-1109 (Sigmaringen: Jan Thorbecke Verlag, 1993), 20614; Cécric Rodon, 'Le réseau monastique dans le diocèse de Saintes du Xe au XIIe siècle' (master's thesis, University of Poitiers 2000); Cécile Treffort, 'Moines, monastères et prieurés charentais au Moyen Âge. Quelques réflexions autour d'un projet collectif en cours', Annales de Bretagne et des Pays de l'Ouest 113 (2006): 167-88, esp. 171-2; and Stéphane Lafaye, 'Les monastères de Cluny en Aquitaine (XIe-XIIIe siècles): Essai de topographie monastique' (PhD diss., University of Paris, 2012). 
Cluny's 'nebula' - a term scholars use to denote a 'nebulous' cohort of institutions with informal links to the Burgundian abbey - through an intervention which took place circa 1010. On this occasion, Duke William V of Aquitaine (d. 1030) 'liberated' the abbey from the oversight of Saint-Cyprien in Poitiers, brought in monks from Saint-Julien in Tours (which had previously adopted Cluny's observance) and gave it a proper abbot instead of (as used to be the case) a prior who was recruited from the nearby abbey of Bourgeuil. From then onwards and continuing during the next two decades, Maillezais provided support for Cluny-inspired interventions at the count's initiative in the abbeys of Saint-Jean d'Angély (in the diocese of Saintes), Saint-Cyprien, and Charroux (both in the diocese of Poitiers). Indicative of William's desire to keep the legal and institutional consequences of these 'Cluniac reforms' in check is his action to exempt the Maillezais estate from lay control whilst keeping a right of refusal over elected abbots. ${ }^{13}$

Following William's death, relations between these 'clunicized' institutions and the ducal family grew more distant. ${ }^{14}$ Beginning in the later 1050 s they once again returned to

${ }^{13}$ Sylvie Refalo, 'Les ducs d'Aquitaine et l'abbaye de Maillezais (vers 970-vers 1100)', in L'abbaye de Maillezais. Des moines du marais aux soldats huguenots (Rennes: Presses Universitaires de Rennes, 2005), 330-2. Also, on the early history of this institution, Jocelyn Martineau and Emmanuel Barbier, 'Au coeur du Marais. L'abbaye de Maillezais aux Xe et XIe siècles: Les données archéologiques récentes', in Monastères entre Loire et Charente, ed. Cécile Treffort and Pascale Brudy (Rennes: Presses Universitaires de Rennes, 2013), 115-29.

${ }^{14}$ Refalo, 'Les ducs', 333-4. On the monastic policies of William VI's wife and then widow Agnes (d. 1068), see also Penelope Johnson, 'Agnes of Burgundy: An Eleventh-century Woman as Monastic Patron', Journal of Medieval History 15 (1989): 93-104. 
prominence, but this time the relationship of these places with Cluniac monasticism would be fundamentally different. In a bull from March 1057, Pope Stephen IX listed the abbeys of Maillezais, Saint-Jean d'Angély, and Saint-Cyprien of Poitiers as properties of Abbot Hugo of Cluny (1049-1109), and on that basis also qualified them as member institutions of the Cluniac federation. ${ }^{15}$ While the precise origin of the Cluniac claim on these three institutions is unclear, once the new Duke William VIII (1058-1086) came to power he immediately capitalized on the connection with the Burgundian abbey to renew the privileged ties that had formerly existed between his family and the three houses.

The resulting new wave of Cluniac 'reforms' relied on a methodology in two parts. In a first, the newly installed count invited Hugo to appoint monks of Cluny - individuals who had previously promised obedience to Hugo and in principle remained bound to that promise for life - to the abbatial role in several major institutions: Goderan in Maillezais, Odo in Saint-Jean d'Angély (both in 1060), Ademar in Saint-Martial of Limoges (1063), and Benedict in Saint-Maixent (in the diocese of Poitiers, 1069). In the second part of this strategy, existing confraternal agreements between these institutions and Cluny (and between the houses themselves) were reactivated and new ones were established. ${ }^{16}$ It was via these places, also, that Cluny's influence rapidly extended into the secular sphere. In 1067, just a few years after Maillezais was 'clunicized', Duke William arranged for Abbot Goderan to be made bishop of Saintes (1067-1073). Goderan's appointment was symptomatic of the close connection between the duke's territorial policies at the time, in

\footnotetext{
${ }^{15}$ Edited in Jacques Paul Migne, Patrologia Latina, 143: c. 879; refer also to the discussion in Dietrich Poeck, Cluniacensis ecclesia. Der cluniacensische Klosterverband (10.-12. Jahrhundert) (Munich: W. Fink Verlag, 1998), 62-3.

${ }^{16}$ Kohnle, Abt Hugo, 207-8 and Refalo, 'Les ducs', 336-7.
} 
particular the consolidation of his control over the Saintes region, and Cluniac expansion. ${ }^{17}$ At the same time it also reflected the growing role of reform agents, papal legates Amatus of Oloron and Hugo of Die most prominently, who at the time were organizing a series of major synods in southern France as part of the Church reformers' battle against simony and lay investiture. Amatus and Hugo are known to have worked closely with Hugo of Cluny when looking for suitable candidates to fill vacant episcopal posts. ${ }^{18}$

But the Cluniacs' rise to prominence in the region went beyond buttressing William's fragile political position. It helped to shape the internal discipline in the region's monasteries, and established confraternal links, redefined abbatial roles, and finally was also instrumental in the campaign against secular investiture and simony. Although the duke kept the region's major abbeys close to his metaphorical chest, the direct acquisition of properties by Cluny's abbot was certainly not out of the question. Already in the later 1060s, Hugo obtained a priory on the inhospitable isle of Aix; and a decade and a half later, William collaborated with him to found the Cluniac abbey of Saint-Jean-deMontierneuf, in the diocese of Poitiers. ${ }^{19}$ Before the end of the century Hugo additionally acquired at least seven parishes in rural parts of the diocese. ${ }^{20}$ And in 1097, Bishop Ramnulf of Saintes (c. 1087-1107) issued a charter in which he gave (or at least tried to) the abbey of Baigne, near the border with the diocese of Angoulême, to Abbot Hugo and

\footnotetext{
${ }^{17}$ André Debord, La société laïque dans les pays de la Charente Xe-XIIe s. (Paris: Picard, 1984), 180-2.

${ }^{18}$ Kriston Rennie, Law and Practice in the Age of Reform: The Legatine Work of Hugh of Die (1073-1106) (Turnhout: Brepols, 2010), esp. 175-86.

${ }^{19}$ Kohnle, Abt Hugo, 212.

${ }^{20}$ Croiset, 'Les établissements', 576-7.
} 
his monastery of Cluny. ${ }^{21}$ To this already impressive picture of rural dependencies and other properties we must add the numerous other 'clunicized' or Cluniac institutions. Around the turn of the eleventh century, Saint-Jean d'Angély owned no fewer than seventy of these, including two major priories but also many parishes. In addition, Cluniac abbeys that were situated outside the diocese, such as Saint-Jean-de-Montierneuf in Poitiers, SaintMartial in Limoges, and Savigny-sur-Bresse in Lyon, owned many parishes in Saintes. ${ }^{22}$

The Cluniacs' stellar rise to prominence in rural parts of the Saintes diocese was matched by the acquisition and subsequent development of a prestigious urban centre. In a charter dated 1081, Duke William declared that he had 'ripped' the sanctuary of SaintEutrope in Saintes 'from lay hands', established it 'in that monastic order', and (at the advice of papal legates Amatus and Hugo and with the consent of the bishop of Saintes and his canons) then gave it to Hugo. ${ }^{23}$ The transaction sparked a flurry of further transactions

${ }^{21}$ Recueil des chartes de l'abbaye de Cluny, vol. 5, ed. Auguste Bernard and Alexander Bruel (Paris: Imprimerie nationale, 1894), nr. 3725, p. 74-5: 'Volumus... ut ab hoc die in sempiternum maneat subjectum idem monasterium monasterio Cluniacensi et omnibus abbatibus Cluniacensibus, sicut omnia sua monasteria sub ordinatis abbatibus Deo servientia sibi subdita cognoscuntur, salvo tamen in omnibus jure pontificali et auctoritate Santonicae sedis'. On Hugo's refusal to accept Baigne, see further at n. 57.

${ }^{22}$ Croiset, 'Les établissements', 578 and Sylvie Dinet Refalo, 'Comtes, moines et aristocrates: Les prieurés charentais des abbayes poitevines (Xe-Xe siècles)', in Monastères entre Loire et Charente, ed. Cécile Treffort and Pascale Brudy (Rennes: Presses Universitaires de Rennes, 2013), 41-9.

${ }^{23}$ Recueil des chartes de l'abbaye de Cluny, vol. 4, ed. Auguste Bernard and Alexander Bruel (Paris: Imprimerie nationale, 1888), nr. 3580, p. 715-6: 'aecclesiam beati martiris 
and frantic building activity, which culminated on 20 April 1096 with Pope Urban II and Bishop Ramnulf dedicating the priory's magnificent new church, a jewel of Romanesque art and architecture. ${ }^{24}$ In the new crypt, the body of the diocese's first bishop, St Eutropius, was laid to rest. ${ }^{25}$ There can be little doubt that all this was understood as a triumphant celebration of Cluny's recent successes and a firm statement that the priory and its occupants would occupy a central role in Saintes society. Attentive observers would also have understood this chain of events as one of portentous significance. From this point in its existence, Saint-Eutrope occupied the place formerly held by Saint-Jean d'Angély: it was now Abbot Hugo's major Cluniac foothold in the diocese of Saintes and an

Eutropii corpore insignem, postquam de manu laicali eripui, et ei libertatem Deo donante adquisivi, consensum etiam constituendi in ea ordinis monastici non solum a predictis vicariis, sed etiam ab episcopo Sanctonensi et canonicis obtinui, transscribo et transfundo... in manum beati Petri Cluniacensis monasterii, cujus abbatem domnum videlicet Hugonem presentem video, ut locus iste ad servitium Dei ordinandus per eum ejusque successores omnibus deinceps temporibus disponatur...'. Also Koehnle, Abt Hugo, 213 and Poeck, Cluniacensis ecclesia, 459-60.

${ }^{24}$ Christian Gensbeitel, 'L'église du prieuré Saint-Eutrope de Saintes, entre culte de reliques et vie monastique: Un monument exceptionnel en réexamen', Les cahiers de Saint-Michel de Cuxa 49 (2018): 69-86.

${ }^{25}$ Raphaël Guerin, 'Reliques, sanctuaire et hagiographie: Le renouveau du culte de saint Eutrope de Saintes aux XIe et XIIe siècles', in Corps saints et reliques dans le Midi, ed. Michelle Fournié, Daniel Le Blévec, and Catherine Vincent (Toulouse: Editions Privat, 2018), 355-74. 
institutional anchor point from which his policies were communicated locally. ${ }^{26}$ Meanwhile, the linking of the priory with the cult of Saintes' first Bishop Eutropius indicated in the most explicit way possible that the Cluniacs were intent on participating in future discussions over worthy candidates for the episcopal throne. Both of these transformations would have disruptive consequences, as we shall see further.

\section{Objections to Cluniac Integration}

The above overview might give us the impression that Charente society unreservedly backed the process whereby the Cluniacs became established in the region, institutionally, economically, and in terms of its prestige and influence. But in reality, there are numerous indications that by the end of the eleventh century, this expansion was approaching the limits of what local agents found tolerable. Scattered in the surviving cartularies of monastic houses we find clues that members of the rural clergy and their relatives resisted the transferral of churches in particular to Cluniac or 'clunicized' institutions. One example that illustrates well the complex stakeholdership of these and other properties concerns the locality of Fontaines-d'Ozillac, in the diocese of Angoulême. Here, three priests challenged the abbot of Baigne's claims to the local church and had to be pacified (in other words compensated) by local Bishop Ramnulf. However, once that dispute was settled, it was the

\footnotetext{
${ }^{26}$ On Saint-Jean's former role, Kohnle, Abt Hugo, 206 and further in this paper. For a discussion of Saintes' sacred urban topography, refer to A. Michaud and Y. Blomme, 'Une cité d'églises et de couvents (XIe-XVe siècle)', in Histoire de Saintes, ed. Alain Michaud (Toulouse: Editions Privat, 1989), p. 101-28, with a map on 104.
} 
local parish priest and his nephew who sought indemnification for the loss of revenues. ${ }^{27}$ Looking at things on a larger scale, we have every reason to suspect that there were concerns among the local clergy and their supporters about the Cluniacs' intentions as regards episcopal elections and about their involvement in clerical administration generally. The appointment of Abbot Goderan of Maillezais as bishop in 1067 no doubt gave these concerns a concrete aspect, ${ }^{28}$ as did other developments such as the acquisition of numerous parish churches in rural parts of the diocese and the emergence in the $1080 \mathrm{~s}-$ 1090s of the priory of Saint-Eutrope as a major cultic centre.

All these disputes and concerns must have troubled the relations between Cluniacs and local agents in the decades on either side of the year 1100 . But any of the resulting conflicts were no doubt vastly overshadowed by those concerning the administration of 'clunicized' monasteries. Beginning in the early 1070s and continuing over the next four decades, members of at least three such institutions - Maillezais, Saint-Jean d'Angély and Baigne - challenged the prerogative of Abbot Hugo and his successor Pontius (1109-1123) to appoint as their leader a monk from Cluny. In the earliest of these cases, which spans the years 1073-1100/1101, the monks of Maillezais spent nearly three decades trying to reverse a process that, they felt, would lead to the complete subordination of their

${ }^{27}$ Cartulaire de l'abbaye Saint-Etienne de Baigne (en Saintonge), ed. Cholet (Niort: L. Clouzot, 1868), nr. 54, p. 34 (charter dated 1098-before 1107) and nr. 397, p. 165-6 (10981109).

${ }^{28}$ When Goderan died in 1073 , the episcopal office once again fell to a non-Cluniac individual named Boso. Just seven years later Boso lost his throne, possibly as a result of accusations of simony; J. Depoin, 'Chronologie des évêques de Saintes de 268 à 1918', Bulletin philologique et historique (1919): 53-4. 
institution to the abbey of Cluny. The 1060 charter that recorded Goderan's appointment suggested that his former status as a monk of Cluny would not fundamentally change a bond of 'love and fraternal society' that had previously existed between the two institutions. ${ }^{29}$ But the monks of Maillezais may well have suspected that the promised relationship between equals would remain dead letter and that Hugo would end up holding their new abbot to his promise of obedience in order to intervene in the administration of their institution. Whatever really happened during Goderan's tenure, on his death in 1073 his community gave the office of abbot to a monk named Drogo. Unlike Goderan, Drogo was recruited not from Cluny but likely from the abbey of Saint-Martial of Limoges. ${ }^{30}$ The choice of an individual from Saint-Martial would have been deliberate. Even though this institution had earlier adopted Cluny's observance and maintained close relations with the Burgundian abbey, ${ }^{31}$ in 1063 it had successfully resisted incorporation into the Cluniac

${ }^{29}$ Lacurie, Histoire de l'abbaye de Maillezais depuis sa fondation jusqu'à nos jours (Fontenay-le-Comte: Edmond Fillon and Saintes: Rose Scheffler, 1852), 209-10: ‘...conservata cum domno Hugone abbate Cluniacense cujus idem est monachus caritativae fraternitatis societate sicut fuit quondam cum suo predecessore sanctissimo videlicet Odilone et patribus nostris Teudone et Humberto ingressis viam universae carnis'. On Goderan, a former monk of Saint-Rémi in Reims and then monk (and possibly also chaplain) of Cluny, Kohnle, Abt Hugo, 207.

${ }^{30}$ Kohnle, Abt Hugo, 207-8.

${ }^{31}$ Stéphane Lafaye, 'Cluny et Saint-Martial de Limoges: Essai sur les relations entre deux grandes abbayes (Xe-XIVe siècles)', Bulletin de la Société Archéologique et Historique du Limousin 136 (2008): 5-35. 
federation. ${ }^{32}$ And while Saint-Martial and Maillezais also had a confraternity agreement, it was not linked to an arrangement whereby the abbot of the former would select one of his monks to lead the latter. ${ }^{33}$ This suggests that Drogo's appointment was part of a move to maintain an informal link with Cluniac monasticism whilst avoiding the risk of ending up in a state of long-term subordination.

By the look of things, however, the Maillezais monks and their associates found that the link between the new abbot and Cluny was still too close for comfort: possibly they also feared that Cluny might at some point successfully challenge Saint-Martial's claim of independence. In 1082 they rebelled against Drogo, deposed him, and elected as their new leader Geoffrey, a monk from the Piedmontese abbey of San Michele della Chiusa. ${ }^{34}$ One of the possible backgrounds to their action was Pope Gregory VII's 1075 privilege for Cluny: unlike earlier such papal documents, this one explicitly distinguished between two categories of properties owned by the abbey, namely (on the one hand) churches, cells and villages, and (on the other) monastic houses. It implied, among other things, that the pope no longer saw the latter category as mere material possessions but as

\footnotetext{
${ }^{32}$ Hubert Claude, 'Le légat Gérard d'Angoulême et la résistance de l'abbaye de Baigne à la centralisation clunisienne', in Mélanges offerts à René Crozet, ed. Pierre Gallais and YvesJean Riou, 2 vols. (Poitiers: Société d'études médiévales, 1966), vol. 1, 515-21, at 516.

${ }^{33}$ Jean-Loup Lemaître, Mourir à Saint-Martial. La commémoration des morts et les obituaires à Saint-Martial de Limoges du XIe au XIIIe siècle (Paris: De Boccard, 1989), nrs. 4,5 , and 13 .

${ }^{34}$ The charter of Geoffrey's appointment survives and is edited in Laurence Brousseau, Edition des actes de l'abbaye de Maillezais de ses origines à 1082 (master's thesis, University of Poitiers, 1995), n. 23, p. 98.
} 
parts of a hierarchically structured federation of religious houses, with the abbey of Cluny as its head. ${ }^{35}$ Shortly afterwards, Gregory also began issuing a series of bulls in which he granted Hugo the right of abbatial investiture (represented by the handing over of the abbatial staff) in a number of these places. ${ }^{36}$ While Maillezais was not listed among them, reports of the contents of these documents and memories of Pope Stephen's 1057 bull may well have resulted in increased anxiety about the abbey's future status.

Like that of Drogo, Geoffrey's election appears to have been a tactical move. Although the distance between Maillezais and San Michele della Chiusa was considerable, the two institutions did have a confraternity agreement that allowed for easy exchange of monastic personnel and close institutional collaboration. ${ }^{37}$ It was based, among other things, on the need for the San Michele monks to manage properties on the Atlantic coast that had been donated to them by the duke of Aquitaine. ${ }^{38}$ But unlike the agreement

${ }^{35}$ Quellen und Forschungen zum Urkunden- und Kanzleiwesen Papst Gregors VII., vol. 1, ed. Leo Santifaller (Vatican City: Bibliotheca Apostolica Vaticana, 1957), nr. 107, p. 1003.

${ }^{36}$ For two examples concerning the abbeys of Montierneuf and Gigny, Ibid., nrs. 108-9.

${ }^{37}$ Brousseau, Edition, n. 23, p. 98: 'confirmamus et conlaudamus hunc fratrem nomine Gaufredum esse nobis domnum et abbatem, concedente domno Benedicto abbate Sancti Michaelis de Clusa karitativae fraternitatis societate...'. Saint-Martial's confraternity records contain no indication that the link was continued or renewed following the end of Drogo's tenure; Lemaître, Mourir.

${ }^{38}$ Treffort, 'Moines', 173-5 and Christian Lauranson-Rosaz, 'L'abbaye de Saint-Michel de la Cluse et le Midi de la Gaule, Xe-XIIIe siècles', in Attraverso le Alpi: S. Michele, Novalese, S. Teofredo e altre reti monastiche, ed. Frederi Arneodo and Paolo Guglielmotti 
between Maillezais and Cluny, this one did not rest on the expectation that the San Michele abbot would have any say over his former monk Geoffrey following the latter's election as abbot of Maillezais. ${ }^{39}$ An added bonus to these precautions was that Cluny had no reasonable claim to San Michele della Chiusa, as it arguably did have to Saint-Martial. Once he was installed, Abbot Geoffrey was tasked with executing the second step in his new institution's emancipation, which was getting rid of its implied subordination to Cluny. In 1090 he formally requested submission to the Holy See, but the affair dragged on and eventually turned to his disadvantage. Several major Church councils of that decade strongly favoured the position of those who were looking to use the principle of permanent obedience of former monks-turned-abbots as a tool to establish stable monastic networks. And while Pope Urban II in the late 1090s contested this principle and put the entire process of Cluniac integration (here and elsewhere) at risk, his successor Paschalis II leant towards the view of major abbots such as Hugo of Cluny. ${ }^{40}$ In $1100 / 1101$, Paschalis

(Bari: Edipuglia, 2008), 39-61. One of the estates belonging to Saint-Jean d'Angély, NotreDame de l'Orivaux was originally founded by a monk from San Michele; Treffort, 'Moines', 174.

${ }^{39}$ Kohnle, Abt Hugo, 208.

${ }^{40}$ Guido Cariboni, "No One Can Serve Two Masters': Abbots and Arch-Abbots in the Monastic Networks at the End of the Eleventh Century', The Journal of Medieval Monastic History 2 (2013): 39-74, at 53-60; also Frans Neiske, 'Papsttum und Klosterverband', in Vom Kloster zum Klosterverband. Das Werkzeug der Schriftlichkeit, ed. Hagen Keller and Franz Neiske (Munich: Fink, 1997), 253-76, esp. 256-62. The pope's response at the time matched the way in which he had handled the slightly earlier conflict between SaintCyprien in Poitiers and Cluny; Kathleen Thompson, The Monks of Tiron. A Monastic 
ordained the submission of Maillezais to Cluny and arranged for all of its future abbots to promise obedience to Hugo or his successors. ${ }^{41}$

These developments must have influenced the second conflict over abbatial appointments, which concerns the abbey of Saint-Jean d'Angély, also mentioned in Pope Stephen's bull. For decades the monks there had accepted former Cluniac monks as their leaders: but in 1104, they clashed with Abbot Hugo over his insistence that they elect his former prior Henry. ${ }^{42}$ According to a document that was included in the local cartulary, the dispute was settled following mediation by Bishop Ramnulf of Saintes and Count William VII of Poitou:

(It was decided that except for Henry) no further individual would be transferred from another monastery to that of Saint-Jean, or to a priory or an obedience. But if there was a need to transfer his own person, then his belongings should be restored to the brothers of his own community, while the properties of the monastery should never be transmitted except in the hands of the sons of that place. For that practice had given cause to grave scandals at that time. Regarding the election it was also decided that following the death of Lord Henry, that person would be abbot whom

Community and Religious Reform in the Twelfth Century (Cambridge: Cambridge University Press, 2014), 100-3.

${ }^{41}$ Refalo, 'Les ducs', 338. Cluny's continued influence in Maillezais' affairs is revealed through a local customary which apparently dates from 1100-1117 and is based on Ulrich's Cluniac customary; Jean Becquet, 'Le coutumier clunisien de Maillezais', Revue Mabillon 55 (1965): 1-31.

${ }^{42}$ Kohnle, Abt Hugo, 206-7. 
the congregation of Saint-Jean would choose, according to the most holy authority, from its own monastery or from that of Cluny. ${ }^{43}$

The terms of the settlement offer us a detailed insight into what it was that the Saint-Jean monks were hoping to avoid. One, a situation where a considerable number of monks from Cluny, all of whom would continue to be bound by their vow of obedience to Hugo, would be brought in, either to take over the governance of Saint-Jean or to simply hollow out the community's autonomy by sheer force of numbers. And two, any state of affairs where the Cluniacs would take Henry's tenure and the existing confraternity agreement as an excuse to regard the two places as a community of property and thus freely transfer estates or other possessions out of the hands of the Saint-Jean community. These two objections represent a fear of losing Saint-Jean's status as an independent abbey and of finding that it was being demoted to a mere priory. ${ }^{44}$ And the mere fact that these

${ }^{43}$ Le cartulaire de l'abbaye royale de Saint-Jean d'Angély, ed. G. Musset, 2 vols. (Paris: Picard and Saintes: Bruneau Saint-Médard, 1901/03), 1: 398-9, at 399: 'Quod utique ita fieret ut non ultra monasterio sancti Joannis, prioratu vel in obedientiis, persona aliqua de alio monasterio mutaretur; sed si mutanda esset, de ipso fratribus restitueretur, nec non res monasterii, nisi in manibus filiorum ejus ecclesiae, nullatenus commiterentur. Gravia enim scandala, pro hoc causa, apud illas tunc temporis extiterant. De electione quoque ita firmatum esset quod, post decessum domni Aenrici abbatis, ille abbas extiteret, quem congregatio sancti Joannis, secundum sacrosanctam authoritatem, de suo coenobio vel de Cluniaco eligeret'.

${ }^{44}$ In 1094, the monks at the priory of Nogent-le-Rotrou near Chartres agreed to appoint an abbot from Chartres but somewhat pathetically indicated that they 'hoped that this in no 
objections are explicitly mentioned in the charter that records the compromise over Henry's appointment indicates they were definitely the subject of public debate.

In addition to these general concerns for Saint-Jean's future, we must also look at the contextual factors that triggered the Saint-Jean monks' rebellion at this particular point in time. To begin with, their institution had recently lost its former position as Hugo's principal foothold in the Saintes diocese, overtaken by the priory of Saint-Eutrope. Secondly, the Saint-Jean must have been aware that Pope Paschalis at the time was actively promoting Cluniac efforts at integration, and that his actions had recently put an end to the emancipatory efforts of their peers at Maillezais and in other places. Now facing a similar fate, the Saint-Jean community in 1104 had every good reason to resist Henry's appointment. And a third and final factor was that the monks over the preceding two decades had been able to witness first hand how institutions lost their independence. Indeed, Saint-Jean itself was directly involved in taking away the autonomy of several houses. To name but two examples, in 1088 Pope Urban II subjected the abbey of Bassac to Saint-Jean; ${ }^{45}$ and in 1090 a local lord named Geoffrey of Tonnay did the same with a former house of canons at Tonnay-Charente. Regarding the latter, now a Benedictine abbey, it was decided that the abbot of Saint-Jean would nominate (and, if necessary, depose) the abbot of Tonnay-Charente in his own chapter; novices at Tonnay-Charente

way would lead to the subjection of (their) monastery' (pro hoc nullam subjectionem de eodem monasterio sibi speraret); Kathleen Thompson, 'Sept textes pour une fondation. Les premiers temps de Saint-Denis de Nogent-Le-Rotrou et leurs réécritures', Bibliothèque de l'Ecole des Chartes 160 (2002): 641-66, at 648.

${ }^{45}$ Le cartulaire de l'abbaye royale de Saint-Jean d'Angély, ed. Musset, 2: XXIX. 
would also do their profession at Saint-Jean. ${ }^{46}$ Resistance after the fact, the Saint-Jean monks well knew, was futile. Less than a decade before their own rebellion, the monks at another of Saint-Jean's dependent houses, Saint-Cybard, rebelled against their subordinated status. No doubt at the instigation of the Saint-Jean abbot himself, they were excommunicated several times and in 1095 were definitively subjected to his institution by papal decree. ${ }^{47}$

These precedents and developments no doubt helped to considerably raise the temperature of pro- and anti-Cluniac debate at the time, among other things because local aristocrats would have become concerned over the protection of their interests and the monastic careers of their relatives. These and other anxieties undoubtedly explain why such prominent agents as the bishop of Saintes and the count of Poitou intervened to broker a deal.

The Baigne Dispute

We may be tempted to view the Maillezais and Saint-Jean d'Angély disputes as evidence of Hugo of Cluny's ruthless policy of incorporation. Twelfth-century testimonies regarding a similar dispute concerning Saint-Cyprien in Poitiers apparently confirm his determination to (as one of Bernard of Tiron's biographers claims) subjugate institutions to Cluny, destroy the freedoms formerly enjoyed by abbeys, and elevate his own position to that of an 'arch-abbot' (archiabbas) ruling over other abbots. ${ }^{48}$ However, the aggressive -

\footnotetext{
${ }^{46}$ Ibid., 1: nr. 207, p. 251-5.

${ }^{47}$ Ibid., nr. 335-6, p. 397-8.

${ }^{48}$ Kohnle, Abt Hugo, 209 and Thompson, The Monks, 102.
} 
destructive, even - nature of Hugo's policies was very much in the eye of the beholder. Several scholars have suggested that the Saint-Cyprien evidence anachronistically projects onto Hugo's leadership the uncompromising views and actions of his successor Pontius and associates. They argue that, instead, Hugo was only interested in keeping the Saint-Cyprien community within the Cluniac fold and maintaining the strictness of their observance by retaining (via his right to approve newly elected abbots, enacted by handing over the abbatial staff) the option of intervening if necessary. ${ }^{49}$ But this 'soft' interpretation of Hugo's approach to institutional integration may be taking the case in his favour a bit too far. As far as we can tell, the abbot of Cluny was genuinely interested in transforming his personal lordship of abbeys into an institutional federation of houses subjected to his main institutions, and in extending the implications of existing confraternal and personal links with other places. ${ }^{50}$ And earlier we already saw how, beginning in the $1070 \mathrm{~s}-1080 \mathrm{~s}$, institutional integration was high on the agenda of many monastic and clerical leaders. ${ }^{51}$ In this context it is likely that Hugo did investigate the possibility of entirely integrating Saint-Jean, and that the definitive submission of Maillezais in 1100/1101 was the outcome of an intentional process.

However, our ability to discern Hugo's exact motives and objectives in these cases is compromised by a number of factors. One is a lack of reliable sources originating from Hugo and his circle. Another is his reluctance to launch the process of integration for

\footnotetext{
${ }^{49}$ Kohnle, Abt Hugo, 209 and Poeck, Cluniacensis ecclesia, 84-91.

${ }^{50}$ Steven Vanderputten, 'The Emergence of the Ecclesia Cluniacensis', in A Companion to The Abbey of Cluny in the Middle Ages, ed. Scott Bruce and Steven Vanderputten (Brill: Leiden, forthcoming).

${ }^{51}$ Refer also to the discussion in Cariboni, 'No One Can Serve Two Masters'.
} 
institutions where there was a risk that former owners and other stakeholders would claim customary rights and other benefits. ${ }^{52}$ And finally, Hugo's willingness to make compromises and strike deals also obscures his precise agenda. The initial stage of the third major dispute over the status of a Saintes institution, that of Baigne, highlights all three of these issues. ${ }^{53}$ Our principal source for the entire affair, which spans the years 1097-1112, is an undated narrative by a monk from Baigne that sets out to describe 'how the monks of Cluny attempted to subject to their power the abbacy of Baigne, which was

${ }^{52}$ Notable cases from the end of the eleventh century are those of the abbeys of SaintBertin and Saint-Germain d'Auxerre (Kohnle, Abt Hugo, 186-91 and Noëlle Deflou-Leca, Saint-Germain d'Auxerre et ses dépendances (Ve-XIIIe siècle). Un monastère dans la société du haut moyen âge (Saint-Etienne: Publications de l'Université de Saint-Etienne, 2010), 281-306). There may be a link between Hugo's position in these and a 1097 papal bull that decreed that all institutions in the Cluniac federation henceforth enjoyed the privileges previously granted to Cluny. From this point onwards, he presumably found the liberated status of all new member institutions essential to the further expansion of the federation; Giles Constable, 'The Interdict- and Excommunication-Privilege for Cluny in the Papal Bulls of 1097 and 1100', in The Abbey of Cluny. A Collection of Essays to Mark the Eleven-Hundredth Anniversary of its Foundation (Berlin: LIT Verlag, 2010), 191-6. In cases where this was not a realistic prospect, Hugo presumably preferred to rely on the tried and tested method of abbatial appointments and confraternity links.

${ }^{53}$ Claude, 'Le légat', 515-21 and Kohnle, Abt Hugo, 209-10. On a recent project to reconstruct the abbey's social and geophysical environment, Pascale Brudy, 'Renseigner une base de données sur les monastères: Le cas de l'abbaye Saint-Etienne de Baignes (Charente)', https://colemon.hypotheses.org/122\#note1 (accessed 14 August 2019). 
established as being free from the beginning, and how as a result of a juridical procedure before Pope Paschalis... their claim was thrown out, and how the abbey of Baigne returned to its former liberty. ${ }^{54}$ On the death of Abbot Gislemund in 1098, it tells us, 'certain secular powers, who ought to be concerned with protecting rather than with destroying the church', were bribed by Arbert, a monk from the priory of Saint-Eutrope, to donate (concessere) Baigne to Cluny. Arbert also persuaded Bishop Ramnulf 'under the pretence of religion' (sub specie religionis) to approve the transfer, however without informing the Baigne monks. ${ }^{55}$ In response, the Baigne community sent two monks to Cluny, Fulco and Arnald Galant, to protest this course of events with Abbot Hugo and his monks. According to the author, Hugo replied that the transfer by these unnamed secular powers was invalid and that he had earlier rejected it at the council of Bordeaux on 5 October $1098 .^{56} \mathrm{In}$ response, Bishop Ramnulf went to Baigne and ordained the elected Abbot Ademar, who thereafter had a peaceful tenure.

${ }^{54}$ Cartulaire de l'abbaye Saint-Etienne de Baigne, ed. Cholet, nr. 3, p. 3-8, at 3-4: ‘...qualiter Beaniensem abbatiam a fundamentis in libertate positam, Cluniacenses monachi sue submittere potestati conati sunt, qualiterque judiciaro ordine ante domnum papam Paschalem... eorum calumpnia destructa fuerit, et Beaniensis abbatia in antiquam redierit libertatem...'

${ }^{55}$ The bishop's charter indicates that the transfer was inspired by a decline in the monks' observance (religio); Recueil des chartes de l'abbaye de Cluny, ed. Bernard and Bruel, 5, nr. 3725 , p. $74-5$.

${ }^{56}$ The only known act of the council of Bordeaux resolved a dispute between the abbeys of Saint-Jean d'Angély and Saint-Maixent over the rights to a church; Odette Pontal, Les conciles de la France capétienne jusqu'en 1215 (Paris: Editions du cerf, 1995), 240. 
Subsequent developments in the Baigne case allow us to speculate on two possible scenarios. In one, a number of agents made a secret deal at this point to renew the attempt to transfer Baigne to Cluny after the death of Abbot Ademar and to arrange for his successor to promise obedience to Hugo. In the other scenario, over the next decade Cluniac agents lobbied to achieve these same two goals. Whichever of the two is correct, by the time Ademar passed away in 1109 , incorporation was definitely on the agenda of a number of individuals both inside and outside the monastery. When the local monks proceeded to elect a former local oblate named Raimund, Fulco along with three other monks rebelled and he himself ascended the abbatial throne. Although the community expelled them, the rebellious group successfully solicited the aid of 'secular powers' and succeeded in having Bishop Ramnulf ordain Fulco. In response, the rest of the Baigne community sent a protest to Pope Paschalis and Archbishop Arnald of Bordeaux, the latter of whom unsuccessfully called Fulco to his court. Fulco also refused to turn up when he was called by Gerard - a papal legate and bishop of Angoulême - to appear at the council of Loudon (held on 18 October 1109); Fulco instead fled to Cluny. ${ }^{57}$ In a crucial passage of the Baigne text, we read that Fulco then 'gave himself and his abbey, as if he was in a position to give her without the consent of the brothers, to the Cluniacs' in the hope that he would be recognized as Baigne's legitimate abbot. ${ }^{58}$ Meanwhile, others were also working for the success of the transferral to Cluny. One such external actor was Bishop Pierre of Saintes (1107/1109-1111). As an archdeacon to Bishop Ramnulf, Pierre had drafted the

\footnotetext{
${ }^{57}$ Kohnle, Abt Hugo, 210.

${ }^{58}$ Cartulaire de l'abbaye Saint-Etienne de Baigne, ed. Cholet, 5: 'seque, ipsqamque abbatiam, ac si eam dare posset, sine fratrum consenu, Cluniacensibus dedit'.
} 
1097 charter of the original donation of Baigne. ${ }^{59}$ Now a bishop himself, he gave Hugo's successor Pontius the chance to undo his predecessor's refusal and in early 1110 issued another charter in which he renewed Ramnulf's donation. ${ }^{60}$ The point of this action was to allow Pontius to legitimately claim that Baigne was indeed part of the Cluniac federation and assert his right to appoint abbots there.

It was at papal legate Gerard's advice that the Baigne monks tried to break a stalemate that seems to have lasted for more than a year. In Fall 1111, not long before or soon after Bishop Pierre's death, they sent a delegation to Rome, which may have mentioned Gerard's lack of support. Pope Paschalis sent a missive dated 19 November 1111 in which he reprimanded Gerard for failing to resolve the conflict and instructed him to call Fulco and question him as to whether his entrance at Cluny (ingressus) was canonical. ${ }^{61}$ But Gerard, who was possibly trying to stall, failed to either call on Fulco or discuss the issue with him. In response, the monks refused to receive Fulco, who had apparently declined to accept the abbacy of Baigne from the abbot of Cluny but instead sought to receive it from the local monks. The monks,

${ }^{59}$ Recueil des chartes de l'abbaye de Cluny, ed. Bernard and Bruel, 5: nr. 3725, p. 75. On the role of archdeacons of the Saintes see in the creation of episcopal charters, Robert Favreau, 'Archidiacres et actes des évêques de Saintes aux XIe et XIIe siècles', in A propos des actes d'évêques. Hommage à Lucie Fossier (Nancy: Presses Universitaires de Nancy, 1991), 265-75.

${ }^{60}$ Recueil des chartes de l'abbaye de Cluny, ed. Bernard and Bruel, 5: nr. 3889, p. 240.

${ }^{61}$ Cartulaire de l'abbaye Saint-Etienne de Baigne, ed. Cholet, 5. 
who refused to submit to the power of another abbey, more so because that abbey had no authority (over them), and striving not to plunge their abbey in poverty, and because it lacked the care of a pastor, and was being destroyed in its external affairs by robbers, ${ }^{62}$

returned to Rome to petition the pope a second time. Paschalis instructed Gerard to hear the Baigne monks' pleas and investigate the canonical nature of the first and second abbatial appointment. He also issued a privilege, reproduced in full in the Baigne narrative, that decreed that no man could 'occupy or alienate or otherwise subject' the monastery. ${ }^{63}$

Gerard then summoned both the monks from Baigne and Fulco to appear before him, but Fulco once again refused and it was decided that the archbishop would proceed with the ordination of Abbot Raimund. But Fulco travelled to Rome to protest Raimund's so-called usurpation and convinced Paschalis to instruct Gerard to depose Raimund and install Fulco. In response, Gerard instructed the Baigne monks to prepare to receive Fulco. But they remained steadfast in their refusal to comply with the pope's orders and declined to receive the usurper:

(The pope) could not force the monks to comply with this juridical order, for it cannot be read in any text of canon law that a monastery should be subjected to

\footnotetext{
${ }^{62}$ Ibid., 5: 'Monachi vero ecclesiam suam alterius ecclesie potestati submittere recusantes, presertum cum nulla hoc habeat acutoritas, ecclesie sue paupertatem non adtendentes, que et pastoris carebat solatio, et exterius raptorum vastabatur incursibus...'.

${ }^{63}$ Ibid., 6: 'ut nulli omnino hominum Beaniense monasterium liceret occupare, alienare, vel alterius ecclesie submittere potestati'.
} 
another monastery against the will of the brothers, particularly based on the authority of the privilege which contains the clause that the abbey of Baigne should not be subjected to the authority of another abbey, but instead ought to be protected by it. $^{64}$

The passage above suggests that the Baigne monks were in principle open to a form of association with Cluny whereby the abbot of the latter would appoint or approve any future leaders of their institution. ${ }^{65}$ In fact, this may well have been a compromise they had settled on in the late eleventh century, when Hugo had rejected Baigne's incorporation. But as we can tell from their attitude in the years 1109-1111, the Baigne community rejected the implication that such an arrangement opened the door to incorporation within Cluny's system: apparently not even Bishop Pierre's 1110 charter for Cluny changed anything about that. In response to the Baigne statement, the new bishop of Saintes, Renaud, and 'other wise men' encouraged papal legate Gerard to invite the parties to Rome, where the pope delegated the matter to two cardinals and two Cluniac monks. The quadrumvirate decided that the election and ordination of Fulco had both been uncanonical, and that Gerard had overstepped his mark. The pope confirmed this sentence on 31 October 1112 and stated that Baigne would retain its original freedom in perpetuity. ${ }^{66}$

\footnotetext{
${ }^{64}$ Ibid., 7: 'Sed monachos ad hoc judiciario ordine impellere non potuit, cum in nullis canonibus legatur quo abbatia abbatiae invits fratribus subdatur, presertim cum privilegii auctoritate in quo continebatur quo Beaniensis abbatia alterius ecclesia potestati non subderetur, sed tuerentur'.

${ }^{65}$ Compare with the comments on Lambert of Saint Bertin below, in note 68 .

${ }^{66}$ Cartulaire de l'abbaye Saint-Etienne de Baigne, ed. Cholet, 8.
} 
Why the opposing parties in the Baigne conflict were unwilling to work towards a compromise arrangement becomes clear if we consider the institutional and interpersonal dynamics at work. Various scholars have noted that towards the end of Hugo's abbacy, a new generation of ambitious Cluniac leaders came to prominence. These individuals, so they argue, no longer wished to take into account the implicit arrangements on which Cluny's involvement in non-incorporated institutions in its confraternal networks were based. ${ }^{67}$ A parallel case to Baigne is that of Saint-Bertin in Flanders, where circa 1100 a deal had been struck whereby the abbey was not integrated into Cluny's federation but Abbot Lambert did vow obedience to Hugo.$^{68}$ Facing significant local pressure following Hugo's death, Lambert argued that his vow did not bind him to Hugo's successor and in March 1112 obtained papal confirmation of the free status of his institution and the community's right to freely elect an abbot. ${ }^{69}$ These acts sparked fierce protest from Abbot Pontius, who according to local chronicler Simon of Ghent behaved as an 'abbot of abbots' (abbas abbatum) and tenaciously pursued Saint-Bertin's integration into the Cluniac

${ }^{67}$ Poeck, Cluniacensis Ecclesia, 62-76; also Giles Constable, 'Cluniac Reform in the Eleventh Century', in The Abbey of Cluny. A Collection of Essays to Mark the ElevenHundredth Anniversary of its Foundation (Berlin: LIT Verlag, 2010), 89-90.

${ }^{68}$ Lambert may have felt that his promise of obedience to Hugo pertained more to the spiritual direction of his community than to administrative matters. At the nearby and recently subordinated abbey of Auchy, he appointed a monk from Cluny as abbot without having obtained Hugo's prior permission; Poeck, Cluniacensis ecclesia, 98-9.

${ }^{69}$ Adriaan H. Bredero, 'A propos de l'autorité abbatiale de Pons de Melgueil et Pierre le Vénerable dans l'ordre de Cluny', in Etudes de civilisation médiévale (IXe-XIIe siècles). Mélanges offerts à Edmond-René Labande (Poitiers: C.E.S.C.M., 1974), 69. 
federation. ${ }^{70}$ It is this attitude, among other things, that caused the conflict over SaintBertin's status to last into the 1130s: and presumably, it also partly explains the acrimonious nature of the conflict over Baigne.

But previous scholars who have looked at the Baigne narrative have failed to recognize that the author is piously discrete about a number of key agents at the time, namely the monks of Saint-Eutrope, Bishop Pierre of Saintes, and papal legate Gerard of Angoulême. However, other sources from the period indicate that their role in the escalation of the conflict was considerable. Looking first at Saint-Eutrope, we find that the priory functioned as a place from where diverse lay, clerical, and monastic agents were targeted in an effort to recruit their support for the Cluniac cause. Earlier we already saw how it was one of the monks there who had intervened with 'secular powers' to make the original transferral of Baigne possible. We may also suspect that he or his fellow inmates coached Fulco and Bishop Pierre when the conflict over Abbot Ademar's succession ignited in 1109. A smoking gun of their close involvement at this stage is that they hosted the ceremony during which Bishop Pierre renewed the donation of Baigne to Cluny. ${ }^{71}$ And finally, there is room to speculate that the Saint-Eutrope monks had been involved in brokering a possible deal over Baigne in 1097/1098 (or at a later point pre-1109) and in recruiting both Fulco and Pierre - both of whom played a prominent role following Ademar's death - to support the subordination of the abbey to Cluny. Looking at the career paths of the two men, it seems plausible that as a trade-off for their support, these men

\footnotetext{
${ }^{70}$ Kohnle, Abt Hugo, 186-91 and Poeck, Cluniacensis ecclesia, 98-9. Simon's claim is in his Gesta abbatum Sithiensium, ed. Oswald Holder-Egger, Monumenta Germaniae Historica. Scriptores 13 (Hanover: Hahnsche Buchhandlung, 1881), 653.

${ }^{71}$ Recueil des chartes de l'abbaye de Cluny, ed. Bernard and Bruel, 5: nr. 3889, p. 240.
} 
were promised (respectively) the abbatial throne of Baigne and the episcopal one of Saintes. Based on all of these indications, it seems clear that the Saint-Eutrope monks over the course of 1097/1098-1109 had deliberately sowed the seeds of discord within the community of Baigne, among Saintes' clerical elite, and even in the region's lay society.

Another dynamic that impacted on the course of the Baigne conflict was that prominent Church leaders, most notably papal legate Gerard of Angoulême, looked favourably on the idea of monastic integration. The Baigne text notes his reluctance to come to the monks' aid because of his 'reverence or, more accurately, his fear of the Cluniacs'. ${ }^{72}$ But other observers understood his motives differently. In a letter to Gerard, Abbot Geoffrey of Sainte-Trinité in Vendôme accused him of simoniac conduct: according to Geoffrey's informants, Gerard had offered to support Fulco on condition that the latter paid him one hundred sous. ${ }^{73}$ In contrast, twentieth-century historians have taken a different tack, suggesting that Gerard was genuinely convinced of the need to subordinate monastic houses to other, more powerful ones. Such motives may have inspired his likely involvement in the $1110 \mathrm{~s}$ transferral of Saint-Amant-de-Boixe (in the diocese of Angoulême) to Saint-Géraud of Aurillac. This transfer sparked a conflict between the two institutions that would linger on until 1197, when an arbitral judgement revealed that the

\footnotetext{
${ }^{72}$ Cartulaire de l'abbaye Saint-Etienne de Baigne, ed. Cholet, nr. 3, p. 5: 'Reverentie, immo ut verius est, timore cluniacensium'. For a benign view on Gerard's attitude, refer to Hubert Claude, Un légat pontifical au XIIe siècle: Girard d'Angoulême. Essai sur l'histoire d'une légation permanente (PhD diss., Université Catholique de Lille, 1949), 949.

${ }^{73}$ Geoffroy de Vendôme, Oeuvres, ed. C. Giordanengo (Turnhout: Brepols, 1996), nr. 136, p. $282-7$, at $284-5$.
} 
abbot of Saint-Géraud had been appointing Saint-Amant-de-Boixe's abbot, prior, cellarer, sacristan, and schoolmaster; that he exercised his right of correctio at Saint-Amant-deBoixe even when its abbot was present; and on those occasions sat on the abbatial throne. ${ }^{74}$ Such an arrangement or a similar one would surely have horrified the Baigne monks: and if Gerard was truly involved, it certainly would explain why they did not regard him as a trustworthy party in the conflict.

The Episcopal Succession Crisis and its Aftermath

From the above discussion we learnt that the final months of 1111 represented a crucial stage in the Baigne dispute. After a stalemate of up to one and a half years following Bishop Pierre's solemn transferral of the abbey to Cluny, the Baigne monks returned to Rome to plead their case before the pope. One of the triggers for this renewed activity, I suggested, was Pierre's death, which took place before 19 November of that year. ${ }^{75}$ While it is possible that the monks were simply hoping to take advantage of the vacancy, their activity was more likely spurred by indications that an even stauncher proponent of Cluniac integration was getting ready to ascend the episcopal throne. That individual was

\footnotetext{
${ }^{74}$ The text of the arbitral sentence is edited in Cartulaire de l'abbaye de Saint-Amant-deBoixe, ed. André Debord (Poitiers: Société archéologique et historique de la Charente, 1982), nr. 280, p. 254-6; also see the commentary Ibid., p. 7-8.

${ }^{75}$ Pierre's exact date of death is unknown, but his successor Renaud is mentioned in a papal bull from 19 November 1111; Cartulaire de l'abbaye Saint-Etienne de Baigne, ed. Cholet, nr. 1, p. 1-2.
} 
Abbot Henry of Saint-Jean d'Angély, a notorious careerist and reputed trouble-maker. ${ }^{76}$ A nobleman from Burgundy, Henry had started his ecclesiastical career as a secular cleric before becoming, in succession, bishop of Soissons (1087/1088-1092), monk of Cluny, prior of Souvigny, prior of Cluny, and finally (in 1104) the abbot of Saint-Jean. Through his family connections, in 1108/1109 he apparently tried to secure the archiepiscopal see of Besançon, but was removed from this post by the abbot of Cluny. ${ }^{77}$ And according to an 1123 papal bull by Calixtus II, on the death of Bishop Pierre of Saintes in 1111, Henry was appointed as caretaker of the episcopal see. ${ }^{78}$ Henry apparently hoped that the Saintes clergy would elect him as bishop: but instead they chose Renaud Chesnel (d. before 17

${ }^{76}$ In a 1104/1105 letter to Hugo of Cluny, Geoffrey of Vendôme stated that Henry was 'a lover of discord, a sower of disputes, and a disturber of the peace'; Geoffroy de Vendôme, Oeuvres, ed. Giordanengo, nr. 65, p. 112-5.

${ }^{77}$ The evidence relating to Henry's career is discussed in Clark, 'This Ecclesiastical Adventurer', with additional notes on his time in England in David Knowles, C.N.L. Brooke, and Vera London, The Heads of Religious Houses: England \& Wales, I. 940-1216 (Cambridge: Cambridge University Press, $2001^{2}$ ), 60. On Souvigny as a step in the Cluniac cursus honorum, Giles Constable, 'Souvigny and Cluny', in The Abbey of Cluny. A Collection of Essays to Mark the Eleven-Hundreth Anniversary of its Foundation (Berlin: LIT Verlag, 2010), 232.

${ }^{78}$ Acta pontificum romanorum inedita. Urkunden der Päpste, ed. Julius Pflugk-Harttung (Tübingen: Akademische Druck- u. Verlagsanstalt, 1881), 1: nr. 283, p. 238-9, at 238: 'Porro abbas in matrice Santonensi ecclesia, episcopo obeunte, cum decanis et archidiaconis primum locum habiturus in electione, et, dum episcopus defunctus vel absens fuerit, cum predictis personis ecclesia in eius providentia remanebit'. 
June 1117), a former canon of Saintes during the tenures of Bishops Ramnulf and Pierre. In response, Henry sought to prevent the bishop-elect from taking office and claimed the episcopal role for himself. ${ }^{79}$

The Saint-Vivien poem which we met at the outset, indicates that it was not just one individual, but an entire cohort of Cluniacs that intrigued against Renaud:

After the death of Peter, a man of great religion/In the hearts of all the clergy originated the question/Who would succeed as bishop of the town of Saintes/Eventually the clergy gathered in council/And jointly and canonically chose one/In whom there flourished such honesty of conduct/That he lacked nothing that would displease to such high office... (But) the monks made him a failure/Pretending to the people that they were deeply committed to the faith. ${ }^{80}$

Based on what we know about the role of Saint-Eutrope in the Baigne dispute, we can safely assume that the attempted coup on the episcopal throne was coordinated from there.

\footnotetext{
${ }^{79}$ Clark, 'This Ecclesiastical Adventurer', 559. Giordanengo rejects the hypothesis that Henry claimed the episcopal throne of Saintes; Geoffroy de Vendôme, Oeuvres, p. 98-9, note 2 .

${ }^{80}$ Recueil, ed. Dufour, 463: 'Petro defuncto, non parvae religionis/Et posito super aethereae sedem regionis/Nascitur in clero cunctos quae quaestio turbat/Quis sit Sanctonicae successor episcopus urbis?/Tandem consilio convenit clerus in unum/Eligit et de canonicis communiter unum/In quo tanta quidem morum pollebat honestas/Ut nil deesset ei quod amaret tanta potestas/De quo quam monachi fecerunt perditionem/In populo magnam simulantes religionem'.
} 
Just as they presumably did with Fulco of Baigne and previously with Bishop Pierre, the Saint-Eutrope monks worked to put Henry in a position where he could secure continued clerical support for Cluniac interests. When it turned out that the local clergy insisted on electing their own candidate to the episcopal throne, the monks assisted Henry in his campaign to tarnish Renaud's reputation. There may also have been an attempt to secure outside support. An intriguing letter by Geoffrey of Vendôme from circa 1113 accuses papal legate Gerard of having offered to remove the new bishop from the see of Saintes as a favour to Henry, in exchange for three hundred sous. He also accused Gerard of having sent Henry written advice on which points he could argue to make the case against Renaud. ${ }^{81}$ And sometime earlier, in 1111-early 1112, Henry corresponded with canon law specialist Bishop Ivo of Chartres, enquiring about lay investiture: given the chronology it is not unlikely that he did so as part of an attempt to build a legal case against Renaud. ${ }^{82}$

The attempted coup on the episcopal throne of Saintes caused tensions over the status of a single monastic house to escalate into a much more dangerous confrontation between Cluniac agents and an increasingly diverse cohort of locals. Critics particularly

${ }^{81}$ Geoffroy de Vendôme, Oeuvres, ed. Giordanengo, nr. 136, p. 282-7, at 286-7. Shortly after Henry's appointment at Saint-Jean d'Angély in 1104, Geoffrey and Henry clashed several times over property rights. In 1104/1105, Geoffrey wrote multiple letters, including to the bishop of Saintes and his archdeacon, the duke of Aquitaine, and Hugo of Cluny to complain about Henry's exactions (Ibid., nr. 55, p. 98-9; nr. 57, p. 100-2; and nr. 65, p. 112-5), but also tried to settle the issue directly with the abbot (nr. 66, p. 116-7).

${ }^{82}$ Of this correspondence, only Ivo's reply to Henry has survived; Lettres d'Yves de Chartres, ed. G. Giordanengo (Orléans, IRHT, 2017), nr. 233, http://telmachartes.irht.cnrs.fr/yves-de-chartres/notice/21171 (accessed 5 August 2019). 
banked on the argument that the Cluniacs had tricked unwitting members of the lay elites into supporting their secret agenda, and that they had bribed, cajoled, or otherwise compelled key members of the monastic and clerical cohorts to participate in a planned takeover of key religious institutions. Comparing the poem that the Saint-Vivien canons inscribed on Mathilde's roll with the Baigne narrative, reveals that a discourse about Cluniac monks being dishonest, misleading members of the laity, and acting against the interests of the local Church was widely shared across institutional and disciplinary boundaries. For its part, the Saint-Eutrope poem indicates that local Cluniacs had responded with fierce verbal violence. ${ }^{83}$ But Cluniac agents who were observing the situation from a greater distance surely realized that the movement's interests in the region were now in serious jeopardy. Whatever their initial response, we find that steps were quickly taken to defuse the situation. According to the Anglo-Saxon Chronicle Pontius deposed Henry from the episcopal throne after just one week: ${ }^{84}$ by Fall 1111 Renaud was

${ }^{83}$ Saint-Eutrope's cartulary, now lost, might have provided insight into the response of secular agents in the priory's social environment. For the scant evidence that remains for this period, see Louis Audiat, 'Saint Eutrope et son prieuré, documents inédits', Archives historiques de la Saintonge et de l'Aunis 2 (1875): 249-448.

${ }^{84}$ Clark, 'This Ecclesiastical Adventurer', 549. Henry's connections to the dukes of Aquitaine and the king of England likely kept him out of the worst trouble: throughout the 1110 s to early 1130 s he remained in place as abbot of Saint-Jean d'Angély and in 1117 he witnessed a judgement of papal legate Gerard of Angoulême in favour of Cluny; Ibid., p. 550. But he was not well regarded: in one of his letters dated $1114 / 1115$, Geoffrey of Vendôme indicated that he was aware of injustices Henry had committed against his monks; and in another from 1118/1119, he complained to Henry that the latter was not 
firmly established as bishop of Saintes. ${ }^{85}$ It must have been Pontius, also, who gave permission to two Cluniac monks to arbitrate in favour of the Baigne community less than one year later. ${ }^{86}$

Mathilde's roll, which as we saw arrived in Saintes less than two years after this final issue was resolved, reveals that individuals on both sides of the conflict were still eager to express their frustration and anger. While the Baigne narrative probably reached only a limited audience, both the Saint-Eutrope and Saint-Vivien poets knew that their

giving the Sainte-Trinité monks their due hospitality; Geoffroy de Vendôme, Oeuvres, ed. Giordanengo, nr. 138, p. 290-3 and nr. 149, p. 324-5. King Henry I of England made him abbot of Peterborough in 1127: but four years later he was deposed there, and the next year the count of Poitou's men ousted him from the abbacy of Saint-Jean; Clark, 'This Ecclesiastical Adventurer', 550 and Giles Constable, 'Cluniac Administration and Administrators in the Twelfth Century', in The Abbey of Cluny. A Collection of Essays to Mark the Eleven-Hundreth Anniversary of its Foundation (Berlin: LIT Verlag, 2010), 347-

8.

${ }^{85}$ Cartulaire de l'abbaye Saint-Etienne de Baigne, ed. Cholet, nr. 1, p. 1-2.

${ }^{86}$ In 1113, Geoffrey of Vendôme accused Gerard of Angoulême of selling the abbacy of Charroux for one thousand sous and imposing his candidate against the wishes of the bishop and the local clergy; Geoffroy de Vendôme, Oeuvres, ed. Giordanengo, nr. 136, 284-5. The name of the abbey's new leader, whose tenure spanned the years 1113-1148, was Fulcadus; Pierre de Monsabert, 'Chartes et documents pour servir à l'étude de l'abbaye de Charroux', Archives Historiques du Poitou 39 (1910): XXXIX. It is possible that this Fulcadus and Fulco are one and the same person. 
work would be widely read along the rest of the roll's journey back to Normandy. ${ }^{87}$ And because mortuary rolls often visited the same regional and institutional destinations, presumably those responsible for the poems were able to roughly predict to what places and areas the roll would travel next. ${ }^{88}$ Although a detailed look at all of these sites is beyond the scope of this paper, even a cursory glance reveals some interesting patterns. After another stop at the nunnery of Notre-Dame of Saintes, the roll travelled on via SaintLéger in Cognac to Angoulême's cathedral and the town's nunnery of Saint-Ausone. Angoulême was, of course, the home base of papal legate Gerard, whom we saw was facing accusations of simony and of playing a dubious role in the Baigne and episcopal succession conflicts. Further stops were made at Saint-Amant-de-Boixe - which may have already been, or was shortly about to be, in the process of being subordinated to SaintGéraud of Auxerre - and Saint-Cybard, which had been subjected in the late eleventh century to Saint-Jean d'Angély.

Then the roll left Charente and travelled west, where it was presented at major episcopal centres in Soissons, Laon, Meaux, Reims, Châlons-en-Champagne, Troyes, Sens, and Auxerre: in all of these places too, the Saint-Vivien canons' fierce warning against the Cluniac attempt on the episcopal throne of Saintes would have been read with great interest. And specifically in the Reims area, the roll was presented at numerous monastic institutions that were involved in the forming of a major network of monastic institutions

\footnotetext{
${ }^{87}$ On indications that the rolliger's hosts read earlier tituli, Goullet, 'Poésie', 167-8. Out of concern that his poem might be misconstrued as an attack against women religious, the Saint-Vivien poet signed off with four lines in Mathilde's honour and with a greeting to 'our friends the nuns' (Valeant monachae amicae nostrae); Recueil, ed. Dufour, 463.

${ }^{88}$ Refer to the maps appended to Recueil, ed. Dufour.
} 
that resisted incorporation in Cluny's federation: in 1131, this campaign would culminate in the proclamation of a major confraternal agreement at the first 'General Chapter' of Benedictine abbots of Reims. ${ }^{89}$ We can only wonder if the two poems influenced the attitudes and actions of these communities and their leadership.

\section{Conclusions}

This case study has shown that resistance to Cluniac integration in the late eleventh and early twelfth centuries was a dynamic process in which membership of both sides in the debate continuously shifted. Expectations and policies were also subject to continuous change, and tactics were simultaneously shaped by local circumstances, decisions taken at the papal court at Cluny, and precedents in other parts of the monastic landscape. The outcomes were variable depending on circumstances. This process of resistance to, and assertion of, Cluniac influence was also one in which the personality, ambitions, and actions of specific individuals had a major impact. But perhaps most importantly, this case study has revealed that it was not so much the principle of integration of monastic governance and institutions that was subject to debate, but the modalities and implications of that integration process. The debate, we find, was not (or was only slightly) the territory of theoreticians and lawmakers. Rather, it was that of monastic leaders and communities who were looking to influence the outcome of the integration process through negotiated deals and compromises. Further study will reveal just how broad the range of possibilities in these deals and compromises was.

\footnotetext{
${ }^{89}$ Steven Vanderputten, 'The 1131 General Chapter of Benedictine Abbots Reconsidered', Journal of Ecclesiastical History 66 (2015): 715-34.
} 